\title{
Kokemus, kasvatus ja demokratia
}

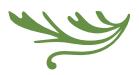

John Deweylle kasvatus näyttäytyy inhimillisen olemassaolon välttämättömänä ehtona. Hänen kasvatusfilosofiassaan koulu ja yhteiskunta muodostavat jatkumon, joka uudistaa ja pitää yllä demokratiaa.

KUIN TOHVELIN SISÄLLÄ Kansalliskirjaston lukusalin temppelissä. Edessäni on rotundan hyllystä selailukappale ja muistikirja, johon merkitsen: Middle Works of John Dewey, 1899-1924. (vol 9) 1916, Democracy and Education. Naapuripöydässä istuva kolisee ja rapisee eväsreissaria ja nokallista vesipulloa.

Kirjoitin pedagogisten opintojen seminaarityötä Bertrand Russellin (1872-1970) kasvatusfilosofiasta. Hän oli muun ohella kiinnostunut kasvatuksesta ja jopa johtanut Beacon Hillin kokeellista koulua Englannissa 1920-luvulla. Silti Russell, kasvatusfilosofina, kuvailtiin harrastelijaksi, jos yleensä edes mainittiin.

Lähdekirjallisuudessa toistuivat neljä teosta: Platonin (427-347 eaa.) Valtio, Jean-Jacques Rousseaun (1712-1778) Émile, John Deweyn (18591952) Democracy and Education sekä Paulo Freiren (1921-1997) Sorrettujen pedagogiikka. Jotta osaisin pelastaa Russellin maineen, minun oli syytä lukea nämä klassikot. Nykyään en antaisi opiskelijan olla perehtymättä muun muassa Nel Noddingsin ja Martha Nussbaumin kirjoituksiin.

Erityisesti minut pysäytti John Dewey, Russellin kovin kilpailija 1900-luvun tunnetuimman anglosaksifilosofin tittelistä.

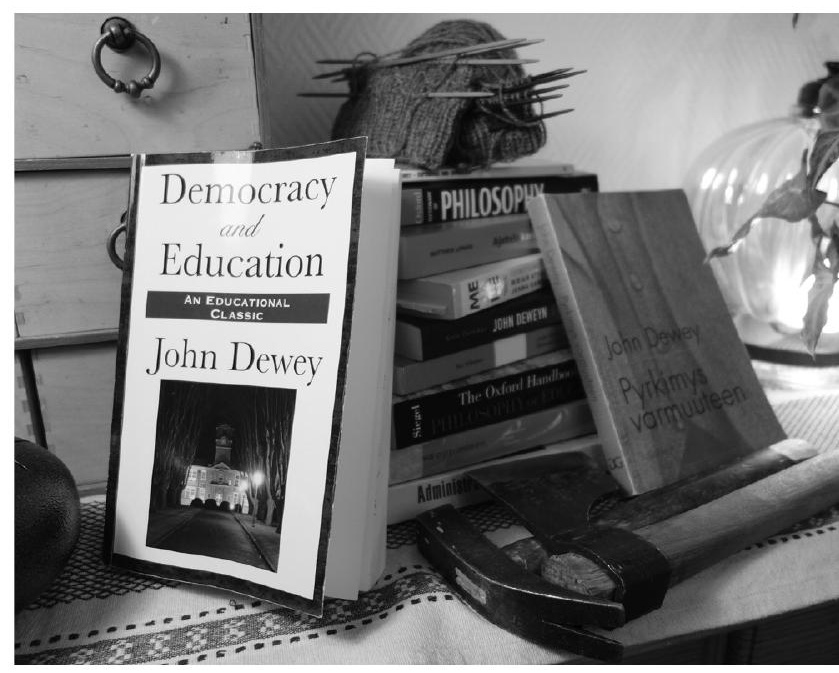

Klassikkoteoksessaan Democracy and Education John Dewey lähestyy oppimista aktiivisena toimintana.

TÄYTYY SUKELTAA SYVEMMÄLLE. Deweyn tunsin jo lukion filosofian jatkokurssilta, sillä opettaja oli perehtynyt Deweyn estetiikkaan. Helsingin yliopistossa uutta suuntaa etsivänä matematiikan opettajalinjalaisena päädyin Pentti Määttäsen filosofian johdanto- 


\section{FILOSOFIA HYLKÄSI}

\section{KASVATUKSEN JA KASVATUS}

\section{FILOSOFIAN.}

kurssille. Hän oli juuri suomentanut Deweyn keskeisen filosofiakritiikin, Pyrkimys varmuuteen.

Määttäsen kertomana Dewey näyttäytyi kiehtovana, esikuvallisena hahmona. Hän oli demokratian puolustaja, joka viimeiseen asti ajoi tasa-arvoa ja osallistui suffragettien mielenosoituksiin. Määttänen siteerasi Deweyn teesiä: "Kasvatusfilosofia on ensimmäinen filosofia, kaikki filosofia koskee lopulta kasvatuksen kysymyksiä."

Ostin tuolloin Gaudeamuksen kampusmyyjäisistä alennuksella Pyrkimyksen varmuuteen - enkä päässyt siinä ensimmäistä lukua pidemmälle.

Kestäisi vielä tusinan vuotta ennen kuin Deweyn kirjoituksiin tarttuisin. Matkan varrella opinnot keskeytyivät, ja toimin Postin työntekijänä. Palasin yliopistolle filosofian pääaineopiskelijana. Aloitin uraa väitöskirjatutkijana. Kunnes ympyrä sulkeutui, ja suoritin aineenopettajan kelpoisuuden seminaarityön aiheenani "Russellin kasvatusfilosofia”. Suuntasin matematiikan opettajaksi yläkouluun ja vapaan sivistystyön ammattilaiseksi Kriittiselle korkeakoululle.

DEMOKRAtia JA Kasvatus. Kirjoitin Kansalliskirjastossa vihkoon: "Rakenne on omituinen. Hypätään kysymykseen kasvatuksen välttämättömyydestä ilman johdantoa." Johdattelevat luvut XXIV-XXVI löytyvät vasta lopusta. Näissä Dewey vihdoin paljastaa, mistä hänen kasvatusfilosofiassa ja sen taustalta vaikuttavissa tieto- ja moraaliteorioissa on kyse. Silmäilevä lukija voisi helposti luulla teosta yleisesitykseksi kasvatustieteestä. Filosofinen lukija sen sijaan löytää useita pohdintoja matkan varrella.

Kirja johdattaa loogisesti kasvatuksen yleisistä kysymyksistä (luvut I-V) kasvatukseen demokraattisessa yhteiskunnassa (VI-VII) ja siitä demokraattisen kasvatuksen metodiikkaan (VIII-XVII). Keskeinen filosofinen kritiikki sisältyy lukuihin XVIII-XXIII. Niissä Dewey tarkastelee, mikä estää kasvatusta olemasta aidosti demokraattista ja demokratiaan kasvattavaa. Ja miksi hänen aikanaan kasvatus oli jopa peräti haitallista lapsille.

Deweyn mukaan syyt löytyvät yhteiskunnallisista asenteista, luokkayhteiskunnasta ja erilaisista filosofisista dualismeista, vastakkainasetteluista mieleen ja kehoon, ihmiseen ja luontoon, havaintoon ja järkeen, yksilöön ja yhteiskuntaan, työhön ja ajatteluun, toimijaan ja toimintaan. Jälkimmäiset yllättäen paitsi oikeuttavat yhteiskunnallisia perusteettomia jaotteluja miesten ja naisten, köyhien ja rikkaiden, työläisten ja omistajien, valkoisten ja värillisten välillä, myös suorastaan ohjaavat kasvatuksellisia valintoja vinoon. Ja uudessa yhteiskunnallisessa kasvatusfilosofiassa ne pitäisi korvata vastakkaisuuksien sijaan jatkumoilla. Siirtyä joko-tai-näkökulmasta sekäettä-ajatteluun.

Tarkastellessaan demokraattisen kasvatuksen perusperiaatteita (luvut VI-VII) Dewey tekee juuri tällaisen tärkeän synteesin kahdesta kasvatusfilosofisesta traditiosta: platonilaisesta konservativismista ja rousseualaisesta naturalismista. Lopputuloksena muodostuu traditionalismin ja progressivismin kuilun ylittävä näkökulma kasvatukseen.

KUKA DEWEY OLI? John Dewey kasvoi filosofiseksi jättiläiseksi 1980-luvulta alkaen. Tämä ei ollut itsestäänselvyys.

Dewey käytännössä dominoi filosofista keskustelua Yhdysvalloissa maailmansotien välillä, ja hänen virallisessa julkaisuluettelossa on kuulemma yli 150 sivua. Siitä huolimatta 1900-luvun alkupuolella kasvatustieteet kääntyivät yksilöpsykologiaan ja behavioristiseen tutkimukseen. Samalla angloamerikkalainen filosofia suuntasi kielen ongelmiin ja hylkäsi käytännön eettiset pohdinnat. Filosofia hylkäsi kasvatuksen ja kasvatus filosofian. 1900-luvun loppupuolella talouskasvu, kulutuskulttuuri ja kapitalismin yltiöindividualistinen ihmiskuva yleistyivät kiihtyen kohti 1980-luvun reaganismia. Talousvetoisessa koulutuspolitiikassa Dewey näkyi irvikuvana, ylitseampuvan ja kalliin progressivismin edustajana. Eikä hänen ajatuksillaan ole ollut sen syvempää vaikutusta Yhdysvaltojen kouluihin.

Kulutuskrapula ja yhteiskunnan, demokratian sekä koulun kriisi 1980-luvulla tekivät Deweystä monien 
silmissä meedion, joka ennakoi demokraattisten yhteiskuntien kipukohdat. Analyyttisessa filosofiassa heräsi kiinnostus kasvatukseen 1960-luvun lopulla, ja seuraavina vuosikymmeninä Dewey paljastui analyyttisen kasvatusfilosofian näkökulmasta ylittämättömäksi. Esimerkiksi Oxford Handbook on Philosophy of Educationia (Siegel 2009) voisi kutsua käsikirjaksi Deweyn ajattelusta. Hänet mainitaan keskimäärin joka kahdeksannella sivulla, ja peräti neljä artikkelia on erityisesti keskittynyt hänen filosofiaan.

Dewey tunnetaan kasvatusfilosofian ja demokratiatutkimuksen lisäksi kokemuksen analyysistä ja estetiikasta. Niin \& Näin -kustantamossa vireillä oleva Democracy and Education -teoksen suomennoshanke, työnimeltään "Demokratia ja kasvatus", paikkaa aukkoa suomalaisessa keskustelussa. Toivoisin vielä suomenkielistä ja nyky-yhteiskuntaan sovitettua tutkielmaa Deweyn kasvatusfilosofiasta.

TAKAISIN KIRJAAN. Chicagon yliopiston professorina ollessaan Dewey perusti yhä toimivan Chicagon laboratoriokoulun vuonna 1896. Democracy and Educationin julkaisun aikoihin hän oli jo kaksi vuosikymmentä työstänyt tarkkaa tutkimusta oppimisen, opettajankoulutuksen sekä kodin, koulun ja yhteiskunnan suhteesta.

Dewey piti filosofiaansa pragmatistisena: teorian merkitys toteutui sen käytännön seurauksissa. Hän hylkäsi sellaiset filosofiset käsitteet kuin totuus ja varmuus filosofisina fiktioina, sillä käytännön näkökulmista ne olivat tyhï̈, jopa haitallisia.

Deweyn kasvatusfilosofian ytimenä on pragmatisteilta, Charles S. Peirceltä (1839-1914) ja William Jamesiltä (1942-1910), vaikutteita saanut näkemys tiedon muodostumisesta. Deweylle oppimiskokemus on aktiivinen tapahtuma. Oppilas osallistuu siihen toimijana, jolla on oma henkilöhistoriansa, elämänkokemuksensa ja ympäristönsä. Tieto itsessään on aktivisuutta: valmiutta toimia, ennakoida ja onnistua. Se muodostaa orgaanisen jatkumon tekemisen ja ajattelun välille, joita ei voi erottaa toisistaan. Tiedon kerääntyminen oppimisprosessissa ei eroa laadullisesti muusta biologisesta sopeutumisesta ympäristöön. Se on yhtäältä ihmisen kasvua siihen moraaliseen ja yhteiskunnalliseen ympäristöön, johon hän kuuluu, ja toisaalta kasvua yhteisönä muuttamaan maailmaa.

Kasvu on Deweylle aitoa kehittymistä, jossa yksilö ja yhteisö ja ympäristö kaikki sopeutuvat muokaten toinen toisiaan. Se on, eroten Aristoteleen ajattelusta, avoimuutta kehittyä tavalla, jolle ei ole ennalta annettua päätepistettä.

Opettaminen on aiemmista kokemuksista syntyvän kiinnostuksen ja motivaation tukemista, ja opittavan asian liittämisestä sen osaksi. Opettajan tehtäväksi muodostuu oppivan yhteisön tukeminen ja mahdollistaminen. Hän tuo ympäristöön oppimisen lähtökohtia, mutta ei yksin sanele oppimisen sisältöä. Opettajan oma osaaminen ja kokemus muodostuvat välineiksi järjestää ja tulkita sekä uudelleen järjestää oppilaan kokemusta.

Oppivalle yhteisölle tarjotaan siis sitä itseään kiinnostavia ja käsinkosketeltavia ongelmia. Lapsi kohtaa tällöin jotain aitoa maailmasta tai yhteiskunnasta, jonka ratkominen saa hänet paremmin sopeutumaan sekä ennakoimaan ja ratkaisemaan onnistuneesti hänen tulevaisuudessa kohtaamiaan tilanteita. Vain tällainen kasvatus antaa oppijalle ja yhteiskunnalle mahdollisuudet ja kyvyt muuttaa maailmaa ja yhteiskuntaa tarvittaessa.

Deweyn mukaan yksilö, koulu ja yhteiskunta pitää nähdä jatkumona. Koulun tehtävänä on paitsi yksilön sopeutuminen demokraattiseen yhteiskuntaan niin myös tämän kasvaminen aktiiviseksi yhteisön ja ympäristön mukauttajaksi, ongelmien ratkaisijaksi. Näin Deweylle koulujen demokraattisuus muodostuu välttämättömäksi.

koulu ja Demokratia. Demokratia on Deweylle erityinen tapa ratkoa itsehallinnollisesti ongelmia luovassa, kuvittelukykyisessä yhteisössä, joka on ihmiselle luonnollinen tapa muodostaa yhteisöjä. Demokraattisuuden ydin on inhimillisen kokemuksen luonne, jonka Dewey määrittää erityisenä yhteisöllisenä suhteena todellisuuteen ja joka muodostaa jatkumon yksilön, yhteisön ja maailman välille. Kokemukset määrittyvät jaetun kielen ja merkitysten kautta. Demokratia ei tule valmiiksi, vaan sen luonteena on muutos, kehittyminen ja sopeutuminen. Suomalaisittain sanottaisiin ehkä jopa: sivistyminen. 
Deweyn kasvatusfilosofia on kriittinen synteesi aiemmasta filosofiasta, aikalaiskritiikki sekä analyysi kasvun, kokemuksen sekä demokratian käsitteistä. Vaikka Dewey pitää itseään pragmatistina, häntä ohjaavat selvästi ennemminkin humanistiset, sosiaaliset ja liberaalit, demokraattiset arvot. Dogmaattisesti tulkittuna pragmatismi itsessään tarjoaa jyrkkää tiedeuskoa, eli skientismiä sekä psykologista behaviorismia. Kumpikaan ei kuvaa Deweya.

Onko hänen ajattelunsa heikkous idealismi? Lapset, ihmiset ja yhteiskunta nähdään luonnostaan kasvuun ja transformaatioon pystyvinä. Deweyn käsitys toimivasta luokkahuoneesta perustuukin ajatukseen tutkijoiden yhteisöstä, ja lapsen uteliaisuus näyttäytyy tieteellisenä uteliaisuutena. Onko näin todella? Tällaisessa ajattelussa voisi kuvitella olevan vaikea löytää tilaa toisenlaisille oppijoille ja oppimisvaikeuksille, saati kielellisille ja sosiaalisille eroille. Hyvin tiedetään, että edistyksellinenkin koulu voi päätyä jakamaan ihmiset menestyjiin ja häviäjiin, jolloin demokraattinen ideaali ei toteudu

Deweyn itsekriittinen teos Experience and Education (1938) onkin tästä syystä tärkeä ja käytännönläheinen opas hänen keskeisiin ajatuksiinsa. Samalla se on Deweyn kasvatusfilosofinen testamentti. Hän painottaa, että kasvatus edellyttää opettajalta laajaa osaamista, näkemystä, suunnitelmallisuutta, eikä opetus voi olla silkkaa lapsen vapautta. Demokratia edellyttää mielikuvituksen lisäksi osaamista ja kurinalaisuutta. Toivoisin tulevassa Democracy and Education -suomennoksesta löytyisi tilaa lyhennelmälle tästä pamfletista.

Dewey ei päästä helpolla sen paremmin opettajia, kouluja tai opintosuunnitelmia kuin yhteiskuntaa. Vaatimukset ovat seuraavat: Yhtäläinen opetus kaikille. Lapsen erityispiirteet huomioiva opetus. Laaja-alainen ja käytännönläheinen, sekä yleissivistävä että taidetta, kädentaitoja ja työntekoa sisältävä opetus. Ilmiöitä tutkiva, uteliasuutta herättävä ja elinikäiseen oppimiseen kannustava opetus. Jotain sellaista, mistä voi tunnistaa suomalaisen peruskoulun.

Näin Deweyn läsnäolo - vaikka hyvin monen käden kautta suodattuneena - on tuntunut jollakin tasolla elämässäni aina. Aloittaessani peruskoulun Sipoossa vuonna 1984 tämä radikaali, demokraattinen koulukokeilu oli jatkunut kunnassa alle vuosikymmenen. Kuluisi vielä melkein kaksi vuosikymmentä ennen kuin Pisa-testit hiljentäisivät järjestelmän kriitikot. Oliko Dewey oikeassa?

DEWEY NYT. Kymmenen vuotta sitten pedagogisessa seminaarityössä kirjoitin suoraviivaisesti: Russellin kasvatusfilosofia oli lähinnä sekavia vaikutteita sieltä ja täältä. Keitossa mukana puolittain mietittyjä, jopa varsin elitistisiä ajatuksia kuorrutettuina kauniilla sanoilla. Sihteeri oli koostanut kirjat ja niillä rahoitettiin koulun toimintaa. Russell oli jo tuolloin kova nimi julkisena ajattelijana.

Suhteeni Deweyyn sen sijaan on muodostunut monijakoiseksi. Kukaan kasvatusfilosofi ei ole ylittänyt häntä, mutta suhtaudun nihkeästi varauksettomaan ihailuun. Deweyn filosofia ei ole ongelmatonta. Se on aikansa kuva.

Deweyn keskeisinä arvoina minulle näyttäytyvät dialogisuus, lapsuuden kunnioitus, demokraattisuus, uudistuksellisuus, tasa-arvo ja voimakkaiden vastakkainasettelujen kavahtaminen. Koulu ja elämä kuuluvat yhteen. Voin allekirjoittaa nämä kaikki. Näen Deweyn voiman pikemminkin hänen arvoissaan kuin teoriapohjassa.

Aikamme huutaa uutta kasvatusfilosofiaa ratkomaan ongelmia: kulutus ja käsistä karannut yltäkylläisyys, ilmastokriisi, informaatioympäristön raju muutos, tekoälyn, algoritmien ja megayritysten valta, uudet välittömästi maasta toiseen loikkaavat globaalit pandemiat, kilpailevat demokratiatulkinnat, populismisi ja demokratian vastaisuus.

Kasvatuksen ja demokratian keskeisin haaste varsinkin Deweyn tarkoittamassa mielessä on globaali ja uusliberaali kapitalismi. Demokraattisuus ei edes ole kapitalistisen talouden edellytys. Esimerkiksi aikamme nouseva talousmahti Kiina panostaa kasvatukseen ja koulutukseen sekä "uudelleenkoulutukseen" tavalla, joka uusintaa kommunismia, vahvistaa kapitalismia ja loukkaa ihmisoikeuksia. Talousliberaalissa Yhdysvalloissa puolestaan kansalaisten luottamus demokratiaan ja instituutioihin on vain jatkanut rapistumista. 
DEWEY JA MINÄ. John Dewey muuttaa ajatteluamme salakavalasti ja epäsuorasti. Hänen kädenjälkensä näkyy tutkivassa oppimisessa ja ilmiölähtöisyydessä, jotka ovat pitkälti suomalaisen nykykasvatuspsykologian ytimessä ja opetussuunnitelmien perusteissa. Se tuntuu filosofiaa lapsille -liikkeessä ja muissa dialogimenetelmissä, kuten Sitran kehittämässä Erätauossa.

Oma kasvatusfilosofiani muodostuu käytännön työssä lasten ja aikuisten viestintä-, demokratia-, digimedialukutaito-, dialogi- ja tunnetaitokasvatuksen parissa. Sivistyskysymysten äärellä pyörin samojen haasteiden parissa kuin Dewey sata vuotta sitten: Kuinka kasvatetaan kriittiseen, muutosvoimaiseen ajatteluun, mutta samalla ymmärrykseen perinteen merkityksestä? Minkälaista osaamista ja kasvatusta tulevaisuuden demokratia edellyttää? Mistä yhteisöllisyys ja halu ratkaista ongelmat rakentavasti keskustelemalla syntyvät? Miten pääsemme yhä kiihtyvistä vastakkainasetteluista huolimatta yhteisen kokemuksen äärelle muodostamaan jaettua ymmärrystä? Kuinka huomioidaan erilaiset kokemustaustat tasavertaisesti?

Olenko kulkenut kohti häntä vai onko hän ohjannut alitajuisesti valintojani? Tähän minulla ei ole vastausta.

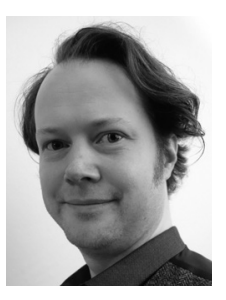

\section{SEVERI HÄMÄRI}

FM, tohtorikoulutettava (käytännöllinen filosofia) Helsingin yliopisto; puheenjohtaja ja puhetaidon opettaja Kriittinen korkeakoulu

(D) https://orcid.org/0000-00033969-1403

\section{LISÄÄ AIHEESTA:}

Dewey, J. (1916). Democracy and Education: An Introduction to the Philosophy of Education. New York: MacMillan. 434 sivua.

\section{LÄHDE}

Alhanen, K. (2013). John Deweyn kokemusfilosofia. Helsinki: Gaudeamus.

Blackburn, S. (1996). Oxford Dictionary of Philosophy. Oxford: Oxford University Press.

Carr, D. (2009). Curriculum and the Value of Knowledge. Teoksessa H. Siegel (toim.) The Oxford Handbook of Philosophy of Education. Oxford: Oxford University Press, 281-299.

Curren, R. (2009). Pragmatist Philosophy of Education. Teoksessa H. Siegel (toim.) The Oxford Handbook of Philosophy of Education. Oxford: Oxford University Press, 489-507.

Dewey, J. \& Dewey, E. (1915). Schools of to-morrow. New York: E. P. Dutton \& co.

Dewey, J. (1899). The School and Society. Chicago: The University of Chicago press.

Dewey, J. (1902). The Child and the Curriculum. Chicago: The University of Chicago press.

Dewey, J. (1910). How We Think. Boston: D.C. Heath \&co.

Dewey, J. (1938). Experience \& Education. New York: Kappa Delta Pi.

Gorham, D. (2005). Dora and Bertrand Russell and Beacon Hill School. The Journal of Bertrand Russell Studies 25, 35-76.
Hakkarainen, K., Lonka, K. \& Lipponen L. (2008). Tutkiva oppiminen, Järki, tunteet ja kulttuuri oppimisen sytyttäjinä (6.-8. painos). Helsinki: WSOY.

Kitcher, P. (2009). Education, Democracy, and Capitalism. Teoksessa H. Siegel (toim.) The Oxford Handbook of Philosophy of Education. Oxford: Oxford University Press, 300-318.

Leiviskä, A. (2018). Kasvatusfilosofia. Logos Encyclopedia, 26.4.2018. https://filosofia.fi/fi/ensyklopedia/ kasvatusfilosofia (26.11. 2021).

Nussbaum, M. (2009). Tagore, Dewey, and the Imminent Demise of Liberal Education. Teoksessa H. Siegel (toim.) The Oxford Handbook of Philosophy of Education. Oxford: Oxford University Press, 52-64.

Puolakka, K. (2021). John Deweyn Estetiikka, Kokemus, luonto ja kulttuuri. Helsinki: Gaudeamus.

Siegel, H. (toim.) (2009). The Oxford Handbook of Philosophy of Education. Oxford: Oxford University Press.

Siljander, P. (2014). Systemaattinen johdatus kasvatustieteeseen. Tampere: Vastapaino. 